\title{
The ANAlysis OF EFFicienCy USINg COIL Meshes WITH AIR POCKeTS UNDER Plastering COMPOSITION
}

\author{
Elena Perlova, Mariia Platonova, Alexandra Pankova, Darya Nemova, Mikhail \\ Petrichenko, Xenyiya Rakova
}

St.Petersburg State Polytechnical University, Polytecknycheskaya st. 29, St. Petersburg, 195251, Russia

\begin{abstract}
As a result of rising prices for heat energy and utilities there is a need to improve the thermal protecting of buildings to reduce heating costs in the operation. One of the ways to increase the energy efficiency of enclosure structure of residential, public and industrial buildings is the use of efficient building materials and facade systems. This paper presents a comparative analysis of the energy characteristics of three-layer wall construction with facing layer of plaster with the use of standard coil meshes and coil meshes with air pockets As a result of comparison, it was found that the use in the construction of the wall plaster meshes with air pockets not only allows you to reach the required level of thermal protection of the building, but also to reduce the cost of construction by reducing the thickness of the insulation.
\end{abstract}

Keyword: Energy efficiency; plaster; coil mesh; coil mesh with air-pocket; facades; low energy consumption; thermal engineering design parameters of building materials; three-layer wall construction with facing plaster
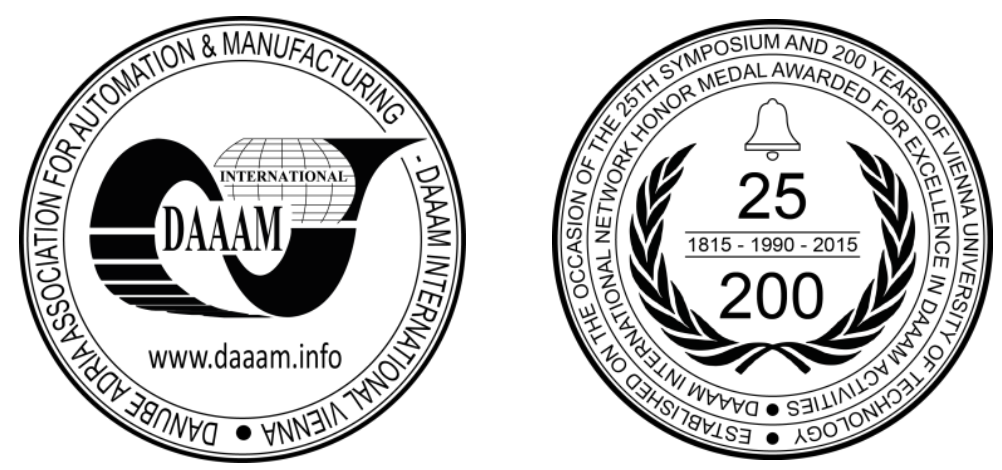

This Publication has to be referred as: Perlova, E[lena]; Platonova, M[ariia]; Pankova, A[lexandra]; Nemova, D[arya]; Petrichenko, M[ikhail] \& Rakova, X[eniya] (2016). The analysis of efficiency using coil meshes with air pockets under plastering composition, Proceedings of the 26th DAAAM International Symposium, pp.0795-0802, B. Katalinic (Ed.), Published by DAAAM International, ISBN 978-3-902734-07-5, ISSN 1726-9679, Vienna, Austria DOI:10.2507/26th.daaam.proceedings.111 


\section{Introduction}

The issue of energy efficiency is an extremely important nowadays. Russia ranks third in worldwide energy consumption and thus spends more energy on GDP unit than any of the countries included in the top ten of the largest energy consumers. The housing is the main province in which it is possible to achieve substantial reductions in the volumes of fuel consumed and, as a result, power consumption, this type of building in according to various estimates, consumes 30 to $40 \%$ of all types of energy resources [1]. Furthermore, the near-term projected growth in energy tariffs, which will significantly increase the cost of heating buildings [2].

One of the ways to increase the energy efficiency of buildings is the use of materials and constructions with high thermal performance. Improvement of enclosure structures by improving their thermal properties have always been given close attention by the technical experts and the state. For example, the local requirements were been increased to thermal resistance of enclosure structure [3].

Today, there are a number of different facade systems. A correct choice of constructive solutions of the façade depends not only the durability and appearance of the building, but also its final cost [4]. One of the finishing of the residential building to ensure conservation of heat and giving the building a neat and aesthetic appearance is an insulated plaster facade. This type of facade systems has a relatively low cost of materials and plastering-painting works, and the use of modern, environmentally friendly and efficient materials, allows for savings on winter heating and summer air conditioning of the house [5,6]. The layer of plaster is kept as long as possible must be properly reinforced by means of a special plaster mesh. Mesh for plaster can be made of metal or polyurethane and fixed to the surface by means of glue, screws or other fixtures that serve the same purpose. Usually it is sold in rolls and can have different sizes [5].

\section{Literature review}

A significant contribution to the theory and practice of energy efficiency and enclosure structures made the following scientists: F. Lembo, A.S. Gorshkov, V. Serra, V.G. Gagarin, O.D. Samarin, V.K. Savin, and many others[721].

V.K. Savin led dependence of energy consumption on the establishment of structures, operating costs and total costs that are presented in dimensionless form, on the level of thermal protection enclosure structure. There is a point on his diagram at which the total cost of energy has the least optimal value at optimum level of thermal protection enclosure structure. If we select the reference enclosure structure, for example, a brick wall, at first by calculation we determine the first optimal value in the dimensional form, and then dimensionless. By this procedure it is possible to select the most energy-efficient materials, structures and products of the building as a whole [7].

A. S. Gorshkov proved in his work according to the basis of the calculations that operating costs can be reduced by increasing the thickness of the insulation in the wall structure. However, this method directly increases the capital cost [8]. That is, it means that the increase of heat transfer resistance of walls will reduce heating costs but given the high capital costs of wall construction. Due to this fact it can be economically inefficient step [9, 10].

Based on the results of the study it can be concluded that activities, aimed at reducing loss of heat and increase of level of thermal resistance of the enclosure structures, entail additional financial investments, which, in turn, increases the payback period of construction. Therefore, the search for solutions to the combined challenges in achieving energy and economic efficiency of construction is as relevant today.

\section{The object of the research}

This paper provides an analysis of the efficacy of polyurethane coil meshes with air pockets under plastering compositions. The calculations are made taking into account climatic characteristics of the city St. Petersburg. The purpose of objective evaluation, the paper provides a comparative analysis using coil meshes with air pockets and standard coil meshes for three-layer wall construction.

\section{Aims and tasks of the study}

\subsection{Main aims:}

- Explore new ways to increase energy saving of buildings;

- To work towards reducing the cost of construction and the consumption of materials;

- The search for new solutions to design problems with the greatest possible positive impact on their field of application.

\subsection{Main tasks:}

- Examine the thermal properties of coil meshes with air pockets, identify the direction of their applications to improve the efficiency of construction; 
- Calculate the estimated heat transfer resistance of the mesh with air pockets, to evaluate the benefits of their use compared to traditional coil mesh;

- Do the thermal comparative calculation of the three-layer wall construction using coil mesh with air pockets and traditional coil mesh, assess their impact on the overall design of the walls and the final cost of construction.

\section{Geometrical characteristics}

Material thickness of coil mesh - $1 \mathrm{~mm}$; in $100 \mathrm{~cm}^{2}$ coil mesh located 20 air pockets that have the shape of truncated cones, smaller diameter (upper base) $-8 \mathrm{~mm}$, larger diameter (lower base) is $-18 \mathrm{~mm}$, the height of the air pocket $8 \mathrm{~mm}$.

To simplify the analytical model the shape of a truncated cone is replaced by an equivalent volume cylinder. The equivalent cylinder has a base diameter equal to the averaged value of the diameters of the upper and lower bases of the original figure is $13 \mathrm{~mm}$ and the height is $8,4 \mathrm{~mm}$.

The calculations should take into account the heterogeneity of the mesh form. The surface density of the pockets $\sigma$ is:

$\sigma=\frac{20}{100} \cdot A$

Where $A$ - the area of the base equivalent of the cylinder, $\mathrm{cm}^{2}$.

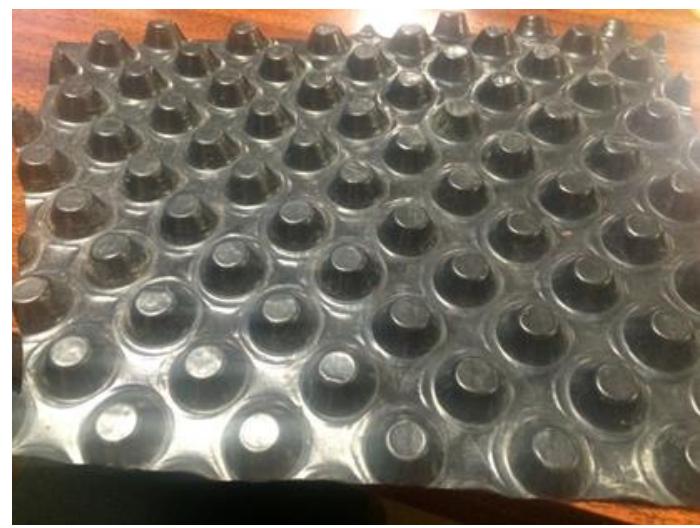

Fig. 1. General view of coil mesh with air pockets

$\sigma=\frac{20}{100} \cdot 1,3=0,26$

\section{Thermophysical characteristics}

\begin{tabular}{lcc}
\hline \multicolumn{1}{c}{ Material } & Thickness of layer, $\delta, m$ & Coefficient of heat conductivity, $\lambda, W /(m * K)$ \\
\hline 1.Coil mesh, polyurethane & 0,001 & 0,01 \\
2. Air that filling the pocket & $0,008,4$ & 0,02 \\
3. Plaster & 0,01 & 0,7 \\
\hline
\end{tabular}

Table 1. Thermal characteristics of the investigated layer

There are thermal characteristics are required for evaluation of the thermal resistance of the mesh with air pockets in the table 1 .

\section{Evaluation of the thermal resistance of the mesh with air pockets}

Thermal resistance of the material layer is determined by the formula in SNIP 23-02-1-2003 "Thermal protection of buildings":

$R=\frac{\delta}{\lambda}$ 
Where $\delta$ - thickness of layer, $m$

$\lambda$ - coefficient of heat conductivity, $W /(m * K)$

Thermal characteristics of layers that used below are shown in table 1.

Thermal resistance mesh:

$R_{l}=\left(\frac{\sigma}{\lambda}\right)_{1}=0,001 / 0,01=0,1 \frac{\mathrm{m}^{2} \cdot K}{W}$

Thermal resistance pocket:

$R_{2}=\left(\frac{\sigma}{\lambda}\right)_{2}=0,0084 / 0,02=0,42 \frac{\mathrm{m}^{2} \cdot K}{W}$

Thermal resistance plaster:

$R_{3}=\left(\frac{\sigma}{\lambda}\right)_{3}=0,01 / 0,7=0,014 \frac{\mathrm{m}^{2} \cdot K}{W}$

Reduced total thermal resistance of coil mesh layer:

$r=\sigma R_{2}+(1-\sigma) R_{1}$

Where $\sigma$ - surface density of the pockets.

$r=0,26 \cdot 0,42+(1-0,26) \cdot 0,1=0,18 \frac{m^{2} \cdot K}{W}$

Then reduced total thermal resistance of plaster layer on coil mesh with air pockets will be equal to:

rlayer $=R_{3}+r$

$r_{\text {layer }}=0,014+0,18=0,194 \frac{\mathrm{m}^{2} \cdot \mathrm{K}}{\mathrm{W}}$

As you can see the value of reduced total thermal resistance for the layer of plaster with the use of coil mesh with air pockets 14 times higher than when using traditional coil mesh.

\section{Comparative analysis of the thickness of the insulation layer in enclosure structure with the use of different types coil mesh}

The climatic parameters of the construction area are taken according to SNiP 23-02-2003 and GOST 30494-96 for St. Petersburg.

\begin{tabular}{|c|c|c|c|}
\hline Index & $\begin{array}{l}\text { Designation of the } \\
\text { parameter }\end{array}$ & $\begin{array}{c}\text { Unit of } \\
\text { measurement }\end{array}$ & $\begin{array}{l}\text { Estimated } \\
\text { value }\end{array}$ \\
\hline Design temperature of outdoor air & $t_{e x t}$ & ${ }^{\circ} \mathrm{C}$ & -26 \\
\hline $\begin{array}{l}\text { The average outdoor temperature during the } \\
\text { heating period }\end{array}$ & $t_{h t}$ & ${ }^{\circ} \mathrm{C}$ & $-1,8$ \\
\hline The duration of the heating period & $z_{h t}$ & day/year & 220 \\
\hline Degree-day heating period & $G_{d}$ & ${ }^{\circ} \mathrm{C} \cdot$ day/year & 4356 \\
\hline Design temperature of indoor air & $t_{e x t}$ & ${ }^{\circ} \mathrm{C}$ & 20 \\
\hline $\begin{array}{l}\text { The heat transfer coefficient of internal surfaces } \\
\text { of fences: for walls, floors and ceilings smooth }\end{array}$ & $\alpha_{\text {int }}$ & $m^{2.0} \mathrm{C} / W$ & 8,7 \\
\hline $\begin{array}{l}\text { The heat transfer coefficient of external surfaces } \\
\text { of fences: for walls and coverings }\end{array}$ & $\alpha_{e x t}$ & $m^{2.0} \mathrm{C} / W$ & 23 \\
\hline
\end{tabular}

Table 2. Design conditions for St. Petersburg 


\subsection{The normalized resistance to transfer of heat}

Degree-day the heating period $G_{d}$ are determined by a formula:

$$
\begin{aligned}
G_{d} & =\left(t_{i n t}-t_{h t}\right) \cdot z_{h t} \\
G_{d} & =(20-(-1,8)) \cdot 220=4796{ }^{\circ} \mathrm{C} \cdot d a y
\end{aligned}
$$

As value $G_{d}$ differs from tabular values, standard value $R_{r e q}$ is defined by a formula:

$$
R_{r e q}=a \cdot G_{d}+b
$$

where $a, b$ - the coefficients accepted on Construction Norms and Regulations 23-02-2003.

The normalized resistance to transfer of heat Rreq is amount to:

$$
R_{r e q}=0,00035 \cdot 4796+1,9=3,58 \frac{m^{2} \cdot{ }^{\circ} \mathrm{C}}{W}
$$

The actual resistance to a heat transfer of a wall of the protecting design before winterization is equal:

$$
R_{0}=\frac{1}{\alpha_{i n t}}+R_{1}+R_{2}+\ldots+R_{n}+\frac{1}{\alpha_{\text {ext }}}
$$

$R_{1}, R_{2}, \ldots, R_{n}$ - thermal resistance of separate layers of the protecting design.

For a uniform layer or uniform sites of a non-uniform layer thermal resistance is determined by a formula (2).

Condition of a sufficient thermal heat-shielding of a design of a wall is expression:

$R_{0} \leq R_{\text {req }}$

If the condition (6) is satisfied, the picked-up structure of a wall can be used in the project.

\subsection{The multilayered protecting design with a usual (traditional) masonry grid}

We will consider the multilayered protecting design with a usual coil mesh (fig. 2). As we defined earlier, according to Construction Norms and Regulations 23-02-1-2003 "Thermal protection of buildings" for climatic conditions of St. Petersburg for residential buildings the minimum resistance to a heat transfer of the protecting wall has to be not less $3,58 m^{2} * K / W$.

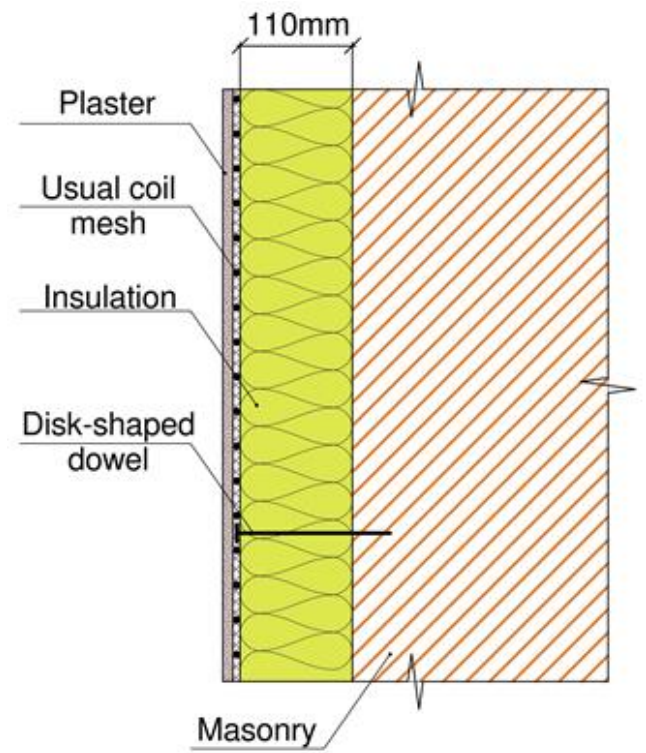

Fig. 2. The multilayered protecting design with a usual coil mesh 
The first version of wall structure consists of three layers:

\begin{tabular}{lcc}
\hline \multicolumn{1}{c}{ Material } & Thickness of layer, $\delta, m$ & Coefficient of heat conductivity, $\lambda, W /(m * K)$ \\
\hline 1. The silicate brick & 0,25 & 0,5 \\
$\begin{array}{l}\text { 2. The mineral-cotton heater } \\
\begin{array}{l}\text { 3. The plaster on a traditional } \\
\text { coil mesh }\end{array}\end{array}$ & $\delta_{2}$ & 0,037 \\
\hline
\end{tabular}

Table 3. Thermal characteristics of the wall members

Consequently, by the formula (7) for achievement of minimum and admissible basic resistance to a heat transfer, the thickness of a heater has to be not less:

$$
\begin{aligned}
& \delta_{2}=\left(R_{0}-\frac{1}{\alpha_{i n t}}-\left(\frac{\sigma}{\lambda}\right)_{1}-\left(\frac{\sigma}{\lambda}\right)_{3}-\frac{1}{\alpha_{e x t}}\right) \cdot \lambda_{2} \\
& \delta_{2}=\left(3,58-\frac{1}{8,7}-\frac{0,25}{0,5}-\frac{0,01}{0,7}-\frac{1}{23}\right) \cdot 0,037=0,108 \mathrm{~m}
\end{aligned}
$$

According to heater standard sizes, we round to bigger and we receive heater layer thickness $\delta_{2}=110 \mathrm{~mm}$.

We will calculate the actual resistance to a heat transfer of a three-layer wall design taking into account the found higher than thickness of a mineral-cotton heater:

$$
R_{0}=\frac{1}{8,7}+\frac{0,25}{0,5}+\frac{0,11}{0,037}+\frac{0,01}{0,7}+\frac{1}{23}=3,77 \frac{\mathrm{m}^{2} \cdot K}{W}
$$

The condition (8) is satisfied.

\subsection{The multilayered protecting design with a masonry grid with air-pockets}

We will consider the multilayered protecting design with a coil mesh with air pockets (fig. 3).

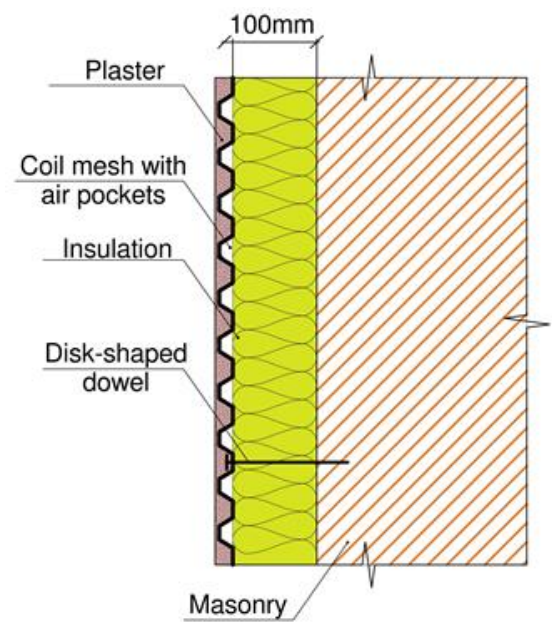

Figure 3. The multilayered protecting design with a masonry grid with air pockets.

The second version of wall structure consists of three layers:

\begin{tabular}{lcc}
\hline \multicolumn{1}{c}{ Material } & Thickness of layer, $\delta, m$ & Coefficient of heat conductivity, $\lambda, W /(m * K)$ \\
\hline 1. The silicate brick & 0,25 & 0,5 \\
$\begin{array}{l}\text { 2. The mineral-cotton heater } \\
\begin{array}{l}\text { 3. The plaster on coil mesh } \\
\text { with air-pockets }\end{array}\end{array}$ & $\delta_{2}$ & 0,037 \\
\hline
\end{tabular}

Table 4. Thermal characteristics of the wall members 
The third layer non-uniform, as its resistance to a heat transfer depends on density of distribution of the air pockets increasing resistance to a heat transfer of all plaster layer.

The specified resistance to a plaster heat transfer on a coil mesh with air-pockets was determined in point 3 and it is equal 0,294 .

Consequently, by a formula (7) for achievement of minimum and admissible basic resistance to a heat transfer, thickness of a heater has to be not less:

$$
\begin{aligned}
& \delta_{2}=\left(R_{0}-\frac{1}{\alpha_{\text {int }}}-\left(\frac{\sigma}{\lambda}\right)_{1}-r_{\text {слоя }}-\frac{1}{\alpha_{\text {ext }}}\right) \cdot \lambda_{2} \\
& \delta_{2}=\left(3,58-\frac{1}{8,7}-\frac{0,25}{0,5}-0,194-\frac{1}{23}\right) \cdot 0,037=0,1 \mathrm{~m}
\end{aligned}
$$

According to heater standard sizes, we round to bigger and we receive heater layer thickness $\delta 2=100 \mathrm{~mm}$. It is possible to notice that when using a coil mesh with air pockets, value of thickness of a heater decreases that allows to cut down expenses on warming of the building considerably.

We will calculate the actual resistance to a heat transfer of a three-layer wall design when using a coil mesh with air-pockets. For carrying out the comparative analysis of energy efficiency of two types of grids, we will accept thickness of a heater, picked up for a traditional coil mesh.

$$
R_{0}=\frac{1}{8,7}+\frac{0,25}{0,5}+\frac{0,11}{0,037}+0,194+\frac{1}{23}=3,82 \frac{\mathrm{m}^{2} \cdot K}{W}
$$

The condition (8) is satisfied.

\section{Conclusion}

In the real work the analysis of efficiency of application of coil meshes with air-pockets under mortar for plastering is carried out and the following conclusions are drawn:

- $\quad$ plaster coat on a coil mesh with air pockets is non-uniform. Its resistance to a heat transfer depends on density of distribution of air-pockets which increase resistance to a heat transfer of all plaster layer;

- the specified plaster coat resistance on a coil mesh with air-pockets is surpasses plaster coat resistance on usual (a traditional grid) in 14 times;

- the demanded thickness of a layer of a heater of the multilayered protecting design with a coil mesh with airpockets is $=100 \mathrm{~mm}$, with a usual coil mesh is $=110$. I.e. is $10 \mathrm{~mm}$ less that will allow to save considerable financial resources at construction of buildings.

Thus, the object under study can be considered energy-efficient material. The principle of energy conservation of the mesh is the presence of pockets filled with air having a relatively low coefficient of thermal conductivity $\lambda$. The method of introducing an additional layer of air in order to improve the thermal characteristics of the wall structure, is used in other façade systems, such as ventilated facade and multi-wall structures with masonry of hollow blocks [16]. These façade systems and other systems with high heat-saving potential can have their strengths and weaknesses that can be explored in further studies. Coil mesh with air pockets can be used everywhere, as insulated plastered facade is often chosen due to the relatively low cost of materials and painting works. And considering the cost-effectiveness of these meshes, namely reducing the cost of insulation of buildings, raise questions about the early introduction into the regular usage of this material.

The construction tendency with application of the technologies directed on increasing of power efficiency of buildings is proved to be one of the most crucial nowadays. The choice for decreasing of energy loss is dictated not only by their rise in price, but also for the purpose of maintaining of the healthy ecological environment as well as preservation of recourses of our planet for future generations [22].

\section{References}

[1] V.I. Mlynchik, A.E. Erastrov, I.A. Vishnevskaya, Metodika opredeleniya potenciala ehnergosberezheniya i perechnya tipovyh meropriyatij po ehnergosberezheniyu i povysheniyu ehnergeticheskoj ehffektivnosti. SRO NP «TI-EH» (2011) p. 76.

[2] N.I. Vatin, D.V. Nemova, P.P. Rymkevich, A.S. Gorshkov, Vliyaniye urovnya teplovoy zashchity ograzhdayushchikh konstruktsiy na velichinu poter teplovoy energii $\mathrm{v}$ zdanii (Influence of level of thermal protection walling on the value of heat losses in a building), Inzhenerno-stroitelnyy zhurnal (Magazine of Civil Engineering) 8 (34) (2012) 4-14. 
[3] N.I. Vatin, D.V. Nemova, P.P. Rymkevich, A.S. Gorshkov, Povyshenie ehnergoehffectivnosti zdanij detskih sadov, Stroitel'stvo unikal'nyh zdanij i sooruzhenij 3 (2012) 52-76.

[4] A.S. Gorshkov, Printsipy energosberezheniya v zdaniyakh (Guidelines for energy efficiency in buildings), Stroitelnyye materialy, oborudovaniye, tekhnologii XXI veka 7 (186) (2014) 26-35.

[5] M.A. Platonova, N.I. Vatin, D.V. Nemova, S.A. Matoshkina, D. Iotti, I. Togo, Vliyanie vozduhoizolyacionnogo sostava na teplotekhnicheskie harakteristiki ograzhdayushchih konstrukcij, Stroitel'stvo unikal'nyh zdanij i sooruzhenij 4(19) (2014) 83-95

[6] V.M. YAkubson, Voprosy ehffektivnosti ograzhdayushchih konstrukcij, Inzhenerno-stroitel'nyj zhurnal 2(12) (2010) 45-54.

[7] V.K. Savin, Uproshchennaya model' minimizacii raskhoda summarnoj ehnergii, idushchej na stroitel'stvo i ehkspluataciyu zdanij.Arhitektura i stroitel'stvo 1 (2010) 80-84.

[8] N.I. Vatin, A.S. Gorshkov, Ehnergoehffectivnost ograzhdayuschih konstrukcij pri kapitalnom remonte, Stroitel'stvo unikal'nyh zdanij i sooruzhenij 3(8) (2013) 1-11

[9] V.I. Livchak, Y.A. Tabunshchikov, Rukovodstvo po raschetu teplopotrebleniya ehkspluatiruemyh zhilyh zdanij, ABOK-8(2007) 45-58

[10] A.N. Dmitriev, I.N. Kovalev, Y.A. Tabunshchikov, N.V. Shilkin, Rukovodstvo po ocenke ehkonomicheskoj ehffektivnosti investicij v ehnergosberegayushchie meropriyatiya, ABOK-PRESS, 2005. 100p.

[11] F. Lembo, Transforming a brutalist monument into an energy efficient building without destroying the formal appealing: The example of the mediterranean bank in potenza (Italy), Springer Proceedings in Physics 155 (2014) 83-90.

[12] Wei Li, Jinzhong Zhu, Zhimin Zhu, The Energy-saving Benefit Evaluation Methods of the Grid Construction Project Based on Life Cycle Cost Theory, Energy Procedia 17(A) (2012) 227-232.

[13] V. Serra, F. Zanghirella, M. Perino, Experimental evaluation of a climate facade: energy efficiency and thermal comfort performance, Energy and Buildings 42(1) (2010) 50-62.

[14] H. Orr, J. Wang, D. Fetsch, R. Dumont, Technical note: Airtightness of older-generation energy-efficient houses in Saskatoon. Journal of Building Physics 36 (2013) 294-307.

[15] M. Gonzalez, R. Machado, J. Gonzalez, Fatigue analysis of PE-100 pipe under axial loading, American Society of Mechanical Engineers, Pressure Vessels and Piping Division (Publication) PVP 6 (PARTS A AND B) (2011) 905-911.

[16] Tayfun Uygunoglua, Ali Kecebasb, LCC analysis for energy-saving in residential buildings with different types of construction masonry blocks, Energy and Buildings 43(9) (2011) 2077-2085.

[17] D. González-Aguilera, S. Lagüela, P. Rodríguez-Gonzálvez, D. Hernández-López, Image-based thermo-graphic modeling for assessing energy efficiency of buildings façades. Energy and Buildings. № 65 (2013) 29-36.

[18] A. Lewandowska, A. Noskowiak, G. Pajchrowski, Comparative life cycle assessment of passive and traditional residential buildings' use with a special focus on energy-related aspects. Energy and Buildings № 67 (2013) 635 646.

[19] A.S. Gorshkov, A.A. Gladkih. Meropriyatiya po povysheniyu ehnergoehffektivnosti v stroitel'stve, Arhitektura i stroitel'stvo 3 (2010) 246-250.

[20] A.S. Gorshkov, Ehnergoehffektivnost' v stroitel'stve: voprosy normirovaniya i mery po snizheniyu ehnergopotrebleniya zdanij. Inzhenerno-stroitel'nyj zhurnal 1 (2010) 9-13.

[21] A.S. Gorshkov, D.V. Nemova, P.P. Rymkevich, Ekonomim ili net? Energosberezheniye 2 (2014) 26-32.

[22] A.S. Gorshkov, S.A. Baykova, A.S. Kryanev, Normativnoye i zakonodatelnoye obespecheniye gosudarstvennoy programmy ob energosberezhenii i povyshenii energeticheskoy effektivnosti i primer yeye realizatsii na regionalnom urovne, Inzhenernyye sistemy, ABOK Severo-Zapad 3 (2012) p. 24. 